\title{
Parent Education and High School Achievement in English as a Foreign Language
}

\author{
Ebrahim Khodadady \\ Ferdowsi University of Mashhad, Iran \\ Email: ekhodadady@ferdowsi.um.ac.ir \\ Farnaz Farrokh Alaee \\ Ferdowsi University of Mashhad, Iran
}

\begin{abstract}
This study explored the relationship between parent education as an indicator of social capital and achievement in English as a foreign language (ELT). To this end, a demographic and a schema-based close multiple choice item test (S-Test) developed on a course textbook were administered to one thousand three hundred and fifty two grade three state high school students in three educational districts in Mashhad, Iran. The performance of students on the S-Test showed that it is a highly reliable measure of ELT achievement which enjoys high internal validity and discriminates significantly among high, middle and low achievers. When the S-Test scores of students whose parents had primary, secondary and higher education were compared with each other, it was found that the students with parents having secondary and higher education scored significantly higher than those with primary education. However, no significant difference could be found between the S-Test scores of the students whose parents had secondary and higher education. The results are discussed and suggestions are made for future research
\end{abstract}

Index Terms - parent education, S-Test, language achievement, high school students

\section{INTRODUCTION}

The sociology of education deals with the effects of education on learners and their outcomes observed in individual experiences. Throughout history, education has often been considered as a cure for social problems on the one hand and an optimistic human endeavor to overcome all inequalities on the other. The cure which has apparently led to wealth and social status. Schools are generally considered as places to equip individuals with high capabilities, the ones which guaranteed good jobs in society, i.e., functional view of sociology (Bonnewitz, 2010).

Yet there is another negative view which considers education as a tool in reproducing inequalities in society. It serves the vicious cycle of transferring power from one hand to another through meritocracies, i.e., conflict view of sociology (Bonnewitz, 2010). It approaches each society as a context of struggles between social groups with different aspirations and socio-economic status.

Different socio-economic statuses of families offer various home resources to students. These differences will affect their school performance and lead to inequalities. It is for this very reason that almost all abiding studies in the field of sociology of education deal with the relationship between educational outcomes and socio-economic status of families. Many studies have, for example, revealed that parents of higher socio-economic status are more involved in their children's education and this kind of involvement brings about higher positive attitudes toward schooling (e.g. Carbonaro, 1998; Dyk \& Wilson, 1999; Furnstenberg \& Hughes, 1995; Lopez, 1996; McNeal, 1999, cited in Dika \& Singh, 2002; Pong, 1998; Smith, Beaulieu \& Israel, 1992; Sui-Chu \& Willms, 1996; Sun, 1998; Teachman, Paasch \& Carver, 1996).

\section{BACKGROUND}

The literature on school achievement has revealed the importance of parents' socio-economic status especially their education on predicting children's achievement (e.g., Dika \& Signh, 2002; Jimerson, Egeland \& Teo, 1999; Kohn, 1963). Using data from a longitudinal study of high risk children, Jimerson, Egeland and Teo (1999), for example, found that families' socio-economic status and mostly their education could be a good predictor of their children's math achievement. The results suggested that children of fathers with high educational degrees showed higher performance in mathematics.

Kohn (1963) found that the parents' social class would affect the quality of their relationships with their children and these quality differences would have a direct influence on the children's school performance. According to him the parents' behavior, values and beliefs stemmed from their socio-economic background, i.e., their social class, income, occupation and education.

In line with Kohn (1963), Davis-Kean (2005), using data from a national cross-sectional study of children between 8 to 12 years old, found that family socio-economic status specifically parents' education and income correlated positively 
with the children's academic achievement. Expectations for children's educational attainment was also directly related to the parents' educational degree (Davis-Kean, 2005) and indirectly reflected children's high achievement (Okagaki \& Frensch, 1978).

In an examination of the relationship between parenting and the school performance Okagaki and Frensch (1978) stated that the parents' beliefs and goals for their children would help them facilitate their school experiences. In their study parents' education was considered as a distal indicator constructing parents' beliefs and values which was indirectly correlated with children's educational attainment.

Using data from a 25-year longitudinal study of birth cohort of over 1000 New Zealand children, Fergusson, Horwood and Boden (2008) revealed a strong association between family socio-economic status and children's academic achievement. In their study family educational aspirations, their economic resources and school factors were analyzed through three model parameters of latent variables, structural model and disturbance covariance. The results showed that parental education levels and their ages were indirectly related to the children's achievement; so that, these factors would affect child cognitive ability at ages 8, 9, and 13. Besides, these factors influence educational aspirations which indirectly and positively affect academic achievement.

Sandefur, Meier and Campbell (2006) used four waves of the National Educational Longitudinal Survey (NELS) to study the influence of parental education, family income and parental investment on the probability of college attendance. The results suggested that parental involvements as their aspirations, expectations and discussions on the school activities with their children along with their educational degree correlated highly with the post-secondary attendance.

In line with the mentioned research projects, Murnane, Maynard, Ohls (1981) provided a review on Coleman Report in 1966 which emphasized the importance of home resources in determining children's cognitive skill levels. The results of the study indicated that the mother's skills and education were critical resources in predicting children's achievement.

Extracting data from the National Longitudinal Survey of Youth, Magnuson (2007) investigated the relationship between mothers' educational attainment and changes in children's academic achievement. In this study mothers' educational levels were increased by additional schooling and their academic skills were examined after the completion of the additional schooling and then the results were compared with their children's academic achievement. The findings suggested that mothers' education can be a good predictor for children's academic achievement in young and loweducated mothers; whereas, older and highly educated mothers' increased knowledge was not a good predictor for their children's achievement.

In a video-taped study, Hyde, et al (2006) found that mothers' mathematics levels caused inequalities in the parental resources available to their children for math learning. During this study, mother-child interactions of the fifth grade American children were videotaped and analyzed while they were working on mathematics problems. Results indicated that the way the mothers conveyed mathematical content differed based on their mathematics preparations.

In an exploratory study McBride, Schoppe-Sullivan and Ho (2005) examined the relationship between family level resources and children's academic achievement. The data for this study comprised 1334 families with children between ages of 5 and 12 from the 1997 Child Development Supplement of the Panel Study of Income Dynamics (PSID). The findings indicated a significant relationship between the variable of father involvement (including fathers' education) and children's academic achievement; while, mother involvement showed less effect on their children's success in education.

The literature review thus shows that there is a positive and significant relationship between parent education and academic achievement in general. However, to the researchers' best knowledge, there is no study available to show whether there is any significant relationship between parents' education and their children's foreign language achievement. To be specific, researchers of this study try to find the relationship between parental education, as an independent indicator of socio-economic status, and grade three high school achievement in English as a foreign language (ELT).

\section{Methodology}

\section{A. Participants}

The participants of this study were the same as those in Khodadady and Alee's (2012a). They were one thousand three hundred and fifty two grade three state high school students, 500 boys (37\%) and 852 girls (63\%), who voluntarily took part in the study. Their age ranged from 16 to 25 (Mean $=17.24, \mathrm{SD}=.72$ ). They formed $10 \%$ of all grade three students in three educational districts of Mashhad, i.e., four, five and nine, representing the high, low and middle social classes, respectively. They all spoke Persian as their mother language.

\section{B. Instruments}

Two instruments were employed in this study, i.e., a demographic scale and a schema-based close multiple choice item test.

\section{Demographic Scale}

The demographic scale (DS) developed by Khodadady and Alaee (2012a) was employed. It deals not only with variables such as participants' age, gender, school type and but also with a number of social indicators such as family 
income and the number of times students change their school. In the present study parents' education (e.g., Anderson $\&$ Minke, 2007) was raised as an item to specify the participants' father and mother education. They were required to choose one of the five points indicating whether they had no education, below high school diploma, high school diploma, BA/BS certificates or higher degrees. Upon collecting the data, the first two points were, however, collapsed to form elementary education as a single point whereas high school diploma was treated as an indicator of secondary education. Bachelorette and higher degrees were also collapsed to form the third point, i.e., higher education. The values of 1,2 , and 3 were finally assigned to primary, secondary and higher education respectively. Along with the DS, a 40-item social capital scale (SCS) was also administered. However, the relationship of the SCS with English achievement and other variables are to be explored and discussed in separate papers.

\section{Schema-Based Close Multiple Choice Item Test (S-Test)}

The schema-based close multiple choice item test (S-Test) developed by Khodadady and Alee (2012b) was administered in this study. It consists of 35 semantic schema, i.e., Afraid, Athletes, Attract, Average, Basis, Build, Choice, Choose, Design, Educate, Events, Excited, Far apart, Fashionable, Fill, Giant, Hand, Heard, Held, Invented, Lose, Loss, Occurs, Orbiting, Painful, Prepare, Recall, Recent, Refuse, Shout, Solve, Spent, Take part, Useful, and Wire, six syntactic schemata, i.e., Among, Each other, Of, Over, Such, and While, and two parasyntactic schemata, i.e., Almost, and Already. However, due to the main syntactic role of parasyntactic schemata, i.e., their dependence on semantic schemata and being many in tokens, they were treated as syntactic in this study.

In addition to having theoretical superiority over traditional multiple choice item tests (Khodadady, 1997), the STests enjoy factorial validity (Khodadady, 2012), being easy to be developed by teachers rather than by testing specialists (Khodadady, 1999), dispensing with artificially written texts written for testing purposes (Khodadady \& Hashemi, 2011), and measuring translation ability indirectly (Seif \& Khodadady, 2003). They also enjoy high levels of reliability and internal validity as shown in Table 1 . As can be seen, not only the S-Test but also its semantic subtest are highly reliable measures of English achievement, i.e., $\alpha=.94$ and .93 , respectively. Although the alpha coefficient of the syntactic subtest is relatively lower, i.e., .62, it is acceptable because it is over four times shorter than the semantic subtest in length.

TABLE 1.

DESCRIPTIVE STATISTICS OF THE S-TEST AND ITS SEMANTIC AND SYNTACTIC SUBTESTS (KHODADADY \& ALEE, 2012, P. )

\begin{tabular}{|l|l|l|l|l|l|l|l|}
\hline Tests & Mean & SD & Kurtosis & Std. Error & Alpha & Mean IF & Mean ID \\
\hline S-Test & 29.01 & 10.250 & -1.105 & .223 & .94 & .67 & .52 \\
\hline Semantic & 24.06 & 8.644 & -1.109 & .223 & .93 & .69 & .54 \\
\hline Syntactic & 4.95 & 2.041 & -.836 & .223 & .66 & .62 & .46 \\
\hline
\end{tabular}

\section{Procedure}

Khodadady and Alaee (2012b) schematically parsed and coded the words/schemata comprising the reading passages of all six lessons comprising English book 3 (Birjandi, Nouroozi, \& Mahmoodi, 2010) taught at grade three in Iranian high schools to develop the S-Test employed in this study. The six paragraphs were also analysed to determine how many types of syntactic, parasyntactic and semantic schema domains were employed in their development. Ten percent of each domain type was then selected to develop the S-Test items. In the selection of the schema domains all attempts were made to avoid the types having the token or frequency of more than one. This procedure was followed so that the second or third occurrence of a given schema type would not be employed by test wise students to choose the keyed response without establishing syntactic, semantic and discoursal relationships between the keyed response and alternatives as well as other schemata constituting the paragraph. For example since the semantic verb schema show had a token of three, i.e., it was used three times, in the first paragraph, no item was developed on this schema type.

Upon the completion of the S-Test, DS and SCS, they were printed together as a test pamphlet consisting of three parts. All the directions given for both scales and S-Test were given in Persian as were the DS and SCS to avoid any possible misunderstanding. The authorities of Education Organization were contacted, and an official letter obtained to go and administer the test booklet in three educational districts. At least one of the researchers attended the schools whose principles and English teachers agreed and secured the voluntary participants of their grade three students in advance. The booklets were distributed among the participants in their class time and they were encouraged to raise whatever questions they had. No participant, however, posed any serious question showing the incompressibility of any item. All the written responses were elicited under standard conditions.

\section{Data Analysis}

The reliability of the achievement S-Test was estimated with Cronbach's Alpha. For determining the internal validity of the test, the item facility (IF) and item difficulty (ID) of all items were calculated. The number of students answering each item correctly was divided by their total number to obtain its IF value. Following Baker (), the IFvalues falling within the range of .25 and .75 were considered acceptable. Each item was also correlated with the total scores on the test to obtain the ID values. The items having IDs equal to and higher than .25 were also considered acceptable. Any item having acceptable IF and ID values was regarded as well functioning. 
The raw scores obtained on the S-Test were converted to Z-scores to divide the participants into three distinct groups. The test takers whose Z-scores fell below -1 were assigned to low achieving group while those with Z-scores equal to +1 and higher were treated as high achievers. The participants having Z-scorers falling between -1 and +1 were considered middle achievers. One-Way ANOVA and post hoc tests were then employed to find out whether the three groups differed significantly from each other. The same tests were also utilized to find out whether there were any significant differences in the educational level of these groups' parents. All descriptive and inferential statistics were estimated by IBM SPSS statistics 19.0 to test the hypotheses below.

H1. The high achievers' mean score on the S-Test will be significantly higher than those of middle and low achievers.

$\mathrm{H} 2$. The S-Test scores of students with fathers having higher education will be significantly higher than those with primary and secondary education.

H3. The S-Test scores of students with mother having higher education will be significantly higher than those with primary and secondary education.

\section{RESULTS AND DISCUSSION}

Table 2 presents the descriptive statistics as well as reliability and internal validity indices of the S-Test. As can be seen, the inclusion of the middle and low social classes in the study has brought about noticeable differences in S-Test statistics. The mean score has dropped drastically from 29 to 22.5 on the total test and from 24.1 to 15.6 on the semantic subtest. They have also increased the internal validity of the S-Test because its mean IF has dropped from .67 to .52, getting very close to mean ID, .50. Similar to the S-Test and semantic subtest, the increase in the mean difficulty level of the test as determined by the performance of all social classes has reduced the reliability of the test as is most tangibly observed in the syntactic subtest. It has dropped from .66 in Khodadady and Alaee's (2012b) study to .59 in the present.

TABLE 2.

DESCRIPTIVE STATISTICS OF THE S-TEST AND ITS SEMANTIC AND SYNTACTIC SUBTESTS

\begin{tabular}{|c|c|c|c|c|c|c|c|}
\hline \multirow{2}{*}{ Tests } & \multirow{2}{*}{ Mean } & \multirow{2}{*}{ SD } & \multicolumn{2}{|l|}{ Kurtosis } & \multirow{2}{*}{ Alpha } & \multirow{2}{*}{ Mean IF } & \multirow{2}{*}{ Mean ID } \\
\hline & & & Statistic & Std. Error & & & \\
\hline S-Test & 22.46 & 10.433 & -1.081 & .133 & .93 & .52 & .50 \\
\hline Semantic & 18.64 & 8.985 & -1.197 & .133 & .92 & .53 & .52 \\
\hline Syntactic & 3.81 & 1.951 & -.576 & .133 & .59 & .48 & .40 \\
\hline
\end{tabular}

Table 3 presents the descriptive statistics of high, middle and low achievers' scores on the S-Test. As can be seen, the mean score of high achievers, 37.6, is higher than that of middle and low achievers, i.e., 21.1 and 9.8, respectively. One Way ANOVA analysis of the mean scores showed that the difference in the mean scores is significant $(\mathrm{F}=2509.376$, df $=2, \mathrm{p}<.0001)$. The Scheffe post hoc test showed that the high achievers scores are significantly different from both middle and low achievers as the middle and low achievers are from the others. (The table is not given to save space.) These results confirm the first hypothesis that the high achievers' mean score on the S-Test will be significantly higher than those of middle and low achievers. They also provide statistical evidence to establish S-Tests as standardized and valid measures of achievement at grade three high schools.

TABLE 3.

DESCRIPTIVE STATISTICS OF THE HIGH, MIDDLE AND LOW ACHIEVERS ON THE S-TEST

\begin{tabular}{|c|c|c|c|c|c|c|c|c|}
\hline \multirow{2}{*}{ Achievers } & \multirow{2}{*}{$\mathrm{N}$} & \multirow{2}{*}{ Mean } & \multirow{2}{*}{ SD } & \multirow{2}{*}{\begin{tabular}{|l} 
Std. \\
Error
\end{tabular}} & \multicolumn{2}{|c|}{ 95\% Confidence Interval for Mean } & \multirow{2}{*}{ Minimum } & \multirow{2}{*}{ Maximum } \\
\hline & & & & & Lower Bound & Upper Bound & & \\
\hline High & 304 & 37.55 & 3.26 & .187 & 37.18 & 37.92 & 33 & 43 \\
\hline Middle & 767 & 21.14 & 5.91 & .213 & 20.72 & 21.55 & 13 & 32 \\
\hline Low & 281 & 9.76 & 2.04 & .122 & 9.52 & 10.00 & 4 & 12 \\
\hline Total & 1352 & 22.46 & 10.4 & .284 & 21.91 & 23.02 & 4 & 43 \\
\hline
\end{tabular}

Table 4 presents the descriptive statistics of English achievement scores of participants whose fathers have had primary, secondary and higher education as their highest level. As can be seen, the mean scores obtained by three groups are different. One Way ANOVA analysis of the mean scores showed that the difference is significant $(\mathrm{F}=$ 53.361, $\mathrm{df}=2, \mathrm{p}<.0001$ ). The post hoc tests, however, showed that the mean score of participants with fathers having higher education is significantly higher than those with primary education.

TABLE 4.

DESCRIPTIVE STATISTICS OF SCORES OBTAINED BY PARTICIPANTS WHOSE FATHERS EDUCATION DIFFERS

\begin{tabular}{|c|c|c|c|c|c|c|c|c|}
\hline \multirow{2}{*}{ Education } & \multirow{2}{*}{$\mathrm{N}$} & \multirow{2}{*}{ Mean } & \multirow{2}{*}{ SD } & \multirow{2}{*}{$\begin{array}{l}\text { Std. } \\
\text { Error }\end{array}$} & \multicolumn{2}{|c|}{ 95\% Confidence Interval for Mean } & \multirow{2}{*}{ Minimum } & \multirow{2}{*}{ Maximum } \\
\hline & & & & & Lower Bound & Upper Bound & & \\
\hline Primary & 721 & 19.85 & 9.24 & .344 & 19.18 & 20.53 & 4 & 43 \\
\hline Secondary & 443 & 25.03 & 10.8 & .513 & 24.02 & 26.04 & 4 & 43 \\
\hline Higher & 188 & 26.43 & 11.2 & .813 & 24.82 & 28.03 & 7 & 43 \\
\hline Total & 1352 & 22.46 & 10.4 & .284 & 21.91 & 23.02 & 4 & 43 \\
\hline
\end{tabular}


Table 5 presents the results of Scheffe post hoc test run on the achievement scores of participants whose fathers' education differs. As can be seen, the mean score of students whose fathers have had only primary education (19.9) is significantly lower than those holding secondary and higher education degrees, i.e., 25 and 26.4, respectively. However, the mean score of those whose fathers have higher education does not differ significantly from that of secondary education graduates and thus partially confirm the second hypothesis.

TABLE 5.

SCHEFFE POST HOC TEST ON THE SCORES OF PARTICIPANTS WITH DIFFERENT EDUCATIONAL LEVELS

\begin{tabular}{|l|l|l|l|l|l|l|}
\hline \multirow{2}{*}{ (I) Education } & \multirow{2}{*}{ (J) } & \multirow{2}{*}{ Mean Difference (I-J) } & \multirow{2}{*}{ Std. Error } & \multirow{2}{*}{ Sig. } & \multicolumn{2}{|l|}{$95 \%$ Confidence Interval } \\
\cline { 5 - 7 } & & & & Lower Bound & Upper Bound \\
\hline \multirow{2}{*}{ Primary } & Secondary & $-5.176^{*}$ & .607 & .000 & -6.66 & -3.69 \\
\cline { 2 - 7 } & Higher & $-6.573^{*}$ & .823 & .000 & -8.59 & -4.56 \\
\hline \multirow{2}{*}{ Higher } & Primary & $5.176^{*}$ & .607 & .000 & 3.69 & 6.66 \\
\cline { 2 - 7 } & Higher & -1.396 & .875 & .280 & -3.54 & .75 \\
\hline
\end{tabular}

Table 6 presents the descriptive statistics of English achievement scores of participants whose mothers have had primary, secondary and higher education as their highest level. As can be seen, the mean scores obtained by three groups are different. One Way ANOVA analysis of the mean scores showed that the difference in the mean scores is significant $(\mathrm{F}=56.654, \mathrm{df}=2, \mathrm{p}<.0001)$. The post hoc tests, however, showed that similar to fathers' education, the difference is not significant for mothers having secondary and higher educations. (The relevant table is not given to save space.) The results thus partially confirm the third hypothesis.

TABLE 6.

DESCRIPTIVE STATISTICS OF SCORES OBTAINED BY PARTICIPANTS WHOSE MOTHERS EDUCATION DIFFERS

\begin{tabular}{|c|c|c|c|c|c|c|c|c|}
\hline \multirow[b]{2}{*}{ Education } & \multirow[b]{2}{*}{$\mathrm{N}$} & \multirow[b]{2}{*}{ Mean } & \multirow[b]{2}{*}{ SD } & \multirow{2}{*}{$\begin{array}{l}\text { Std. } \\
\text { Error }\end{array}$} & \multicolumn{2}{|c|}{$95 \%$ Confidence Interval for Mean } & \multirow[b]{2}{*}{ Minimum } & \multirow[b]{2}{*}{ Maximum } \\
\hline & & & & & Lower Bound & Upper Bound & & \\
\hline Primary & 877 & 20.34 & 9.55 & .322 & 19.71 & 20.98 & 4 & 43 \\
\hline Secondary & 369 & 26.05 & 10.8 & .556 & 24.96 & 27.14 & 6 & 43 \\
\hline Higher & 106 & 27.52 & 11.5 & 1.114 & 25.31 & 29.73 & 7 & 43 \\
\hline Total & 1352 & 22.46 & 10.4 & .284 & 21.91 & 23.02 & 4 & 43 \\
\hline
\end{tabular}

The findings of the present study are partially in line with those of McBride, Schoppe-Sullivan and Ho (2005), Murnane, Maynand and Ohls (2006) and Sandefur, Meier and Campbell (2006) in that they establish a significant relationship between parents education and their children's English achievement. The grade three high school students whose fathers and mothers have had secondary and higher education perform significantly higher than those whose parent have only had primary education. However, the children of those parents who hold higher education degrees do not achieve higher scores on English than those who hold high school diplomas. The findings thus show that the higher education of parents does not produce any inequality in English achievement.

\section{CONCLUSION}

In order to find out whether the educational level of parents, i.e., primary, secondary or higher, relates significantly to achievement in English as a foreign language (EFL) at grade three in Iranian state high schools in Mashhad, Iran, or not, a demographic scale (DS) was developed and administered along with a schema-based cloze multiple choice item test (S-Test). The 1352 students' performance on the S-Test showed that the third graders whose fathers and mothers held secondary and higher education certificates performed significantly higher than those having parents with primary education. However, no significant difference could be found in the EFL achievement of third graders with parents having secondary and higher education. A replication study is needed to find out whether this relationship holds true in other cities of Iran. Exploring the relationship between parent education and EFL achievement at other grades in general and grade 12 or pre-university in particular may shed more light on the relationship.

\section{REFERENCES}

[1] Anderson, K. J. \& Minke, K. M. (2007). Parent involvement in education: Toward an understanding of parents' decision making. Journal of Educational Research, 100(5), 311-323.

[2] Birjandi, P., Nouroozi, M., \& Mahmoodi, G. (2010). English book 3. Tehran: Ketabhaye Darsie Iran Publication.

[3] Bonnewitz, P. (2010). The sociology of Pierre Bourdieu. Tehran; Agah Publishing House.

[4] Carbonaro, W. (1998). A little help from my friends' parents: Intergenerational closure and educational outcomes. American Journal of Sociology, 94 (Issue supplement), S95-S120.

[5] Davis-Kean, P. E. (2005). The influence of parent education and family income on child achievement: The indirect role of parental expectations and home environment. Journal of Family Psychology, 19 (2), 294-304.

[6] Dika, S.L., Singh, K. (2002). Applications of social capital in educational literature. Review of Educational Research, 27 (1), 31-60. 
[7] Dyk, P. H., \& Wilson, S. M. (1999). Family-based social capital considerations as predictors of attainment among Appalachian youth. Sociological Inquiry, 69(3), 477-503.

[8] Fergusson, D.M., Horwood, L.J., \& Boden, J.M. (2008). The transmission of social inequality: examination of the linkages between family socioeconomic status in childhood and educational achievement in young adulthood. Research in Social Stratification and Mobility, 26, 277-295.

[9] Furstenberg, F., \& Hughes, M. (1995). Social capital and successful development among at-risk youth. Journal of Marriage and the Family, 57(3), 580-592.

[10] Hughes, J. (1995). Issues of interpretation. In J. A. Hughes, Wes W. Peter, \& J. Martin (Eds.) Understanding classical sociology. Great Britain: The Cromwell Press, Trowbridge, Wiltshire.

[11] Hyde, J. S., Else-Quest, N. M., Alibali, M. W., Knuth, E., \& Romberg, Th. (2006). Mathematics in the home: Homework practices and mother- child interactions doing mathematics. The Journal of Mathematical Behaviors, 25 (2), 136-152.

[12] Jimerson, S., Egeland, B., \&Teo, A. (1999). A longitudinal study of achievement trajectories factors associated with change. Journal of Educational Psychology, 91, 116-126.

[13] Khodadady, E. (1997). Schemata theory and multiple choice item tests measuring reading comprehension. Unpublished PhD thesis, the University of Western Australia.

[14] Khodadady, E. (1999). Multiple-choice items in testing: Practice and theory. Tehran: Rahnama.

[15] Khodadady, E. (2009). Objective-based achievement testing in the context of schema theory. Iranian Journal of Language Studies (IJLS), 3(1), 1-30.

[16] Khodadady, E. (2012). Validity and tests developed on reduced redundancy, language components and schema theory. Theory and Practice in Language Studies, 2(3), 585-595.

[17] Khodadady, E. Pishghadam, R., \& Fakhar, M. (2010). The relationship among reading comprehension ability, grammar and vocabulary knowledge: An experimental and schema-based approach. Iranian EFL Journal, 6(2), 7-49.

[18] Khodadady, E., \& Alaee, F. F. (2012a). Designing and validating a social capital scale within a grade specific context. European Journal of Educational Studies, 4(1), 701-717.

[19] Khodadady, E., \& Alaee, F. F. (2012b). Exploring the Relationship between Social Capitals and English Language Achievement within a Specific Grade and Context. English Language Teaching, 5 (2),

[20] Khodadady, E., \& Elahi, M. (2012). The Effect of Schema-Vs-Translation-Based Instruction on Persian Medical Students' Learning of General English. English Language Teaching, 5(1), 146-165.

[21] Khodadady, E., \& Hashemi, M. (2011). Validity and C-Tests: The Role of Text Authenticity. Iranian Journal of Language Testing, 1(1), 1-12.

[22] Khodadady, E., \& Herriman, M. (2000). Schemata theory and selected response item tests: from theory to practice. In A. J. Kunnan (Ed.), Fairness and validation on language assessment (pp. 201-222). Cambridge: CUP.

[23] Kohn, M. L. (1963). Social class and parent-child relationships: An interpretation. American Journal of Sociology, 68, 471-480.

[24] Lopez, E. (1996). Social capital and the educational performance of Latino Non-Latino youth: Research Report 11. San Luis Obispo, CA: Julian Samora Research Institute.

[25] Magnuson, K. (2007). Maternal education and children's academic achievement during middle childhood. Developmental Psychology, 43 (6), 1497-1512.

[26] McBride, B. A., Schoppe-Sullivan, S. J., \& Ho M-H. (2005). The mediating role of fathers' school involvement on student achievement. Journal of Applied Developmental Psychology, 26 (2), 201-216.

[27] McNeal, R. (1999). Parental involvement as social capital: Differential effectiveness on science achievement, truancy, and dropping out. Social Forces, 78(1), 117-144.

[28] Morgan, S., \& Scrensen, A. (1999). Parental networks, social closure, and mathematics learning: A test of Coleman's social capital explanation of school effects. American Sociological Review, 64, 661-681.

[29] Morrow, V. (2001).Using qualitative methods to elicit young people's perspectives on their environments: Some ideas for community health initiatives. Health Education Research, 16 (3), 255-268.

[30] Muller, C. (2001). The role of caring in the teacher-student relationship for at-risk students. Sociological Inquiry, 71(2), 241255.

[31] Muller, C., \& Ellison, C. G. (2001). Religious involvement, social capital, and adolescents' academic progress: Evidence from the National Education Longitudinal Study of 1988. Sociological Focus, 34(2), 155-183.

[32] Murnane, R.J., Maynard, R. A., \& Ohls, J. C. (1981). Home resources and children's achievement. The Review of Economics and Statistics, 63(3), 369-377.

[33] Okagaki, L., \& Frensch, P. A. (1978). Parenting and children's school achievement: A multiethnic perspective. Psychological Bulletin, 85 (2), 295-324.

[34] Pong, S. (1998). The school compositional effect of single parenthood on 10th-grade achievement. Sociology of Education, 71, 24-43.

[35] Sandefur, G., Meier, A., \& Hernandez, P. (1999). Families, social capital and educational continuation. Center for Demography and Ecology, University of Winsconsin-Madison, (Working Paper No. 99-19). Retrieved April, 22, 2011, from www.ssc.wisc.edu/cde/cdew/99-19pdf

[36] Seif, S., \& Khodadady, E., (2003) Schema-based cloze multiple choice item tests: measures of translation ability. Universite de Tabriz, Revue de la Faculte des Letters et Sciences Humaines, Langue, 187(46), 73-99.

[37] Smith, M. H., Beaulieu, L. J., \& Israel, G. D. (1992). Effects of human capital and social capital on dropping out of high school in the South. Journal of Research in Rural Education, 8(1), 75-87.

[38] Sui-Chu, E. H., \& Willms, J. D. (1996). Effects of parental involvement on eighth-grade achievement. Sociology of Education, 69 (2), 126-141.

[39] Sun, Y. (1998). The academic success of East-Asian-American students: An investment model. Social Science Research, 27,432-456. 
[40] Teachman, J ., Paasch, K., \& Carver, K. (1996). Social capital and dropping out of school early. Journal of Marriage and the Family, 58,773-783.

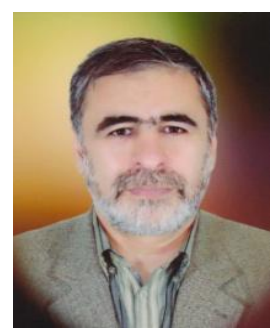

Ebrahim Khodadady was born in Iran in 1958. He obtained his $\mathrm{PhD}$ in Applied Linguistics from the University of Western Australia in 1998. He holds TESL Ontario and Canadian Language Benchmarks Placement Test (CLPBPT) certificates and has taught English as a first, second and foreign language to high school and university students in Australia, Canada and Iran.

$\mathrm{He}$ is currently an academic member of English Language and Literature Department at Ferdowsi University of Mashhad, Iran. He was invited as a VIP by Brock University in Canada in 2004 and served as the Associate Director of Assessment Center at George Brown College in Toronto for almost a year. His published books are Multiple-Choice Items in Testing: Practice and Theory (Tehran, Rahnama, 1999), Reading Media Texts: Iran-America Relations (Sanandaj, Kurdistan University, 1999) and English Language Proficiency Course: First Steps (Sanandaj, Kurdistan University, 2001). His main research interests are Testing, Language Learning and Teaching.

Dr. Khodadady is currently a member of Teaching English Language and Literature Society of Iran (TELLSI), TESL Ontario and European Society for Translation Studies. He is on the editorial board of Ferdowsi Review: An Iranian Journal of TESL, Literature and Translation Studies and has reviewed some research papers for Iranian Journal of Applied Linguistics and TESL Canada Journal as a guest reviewer.

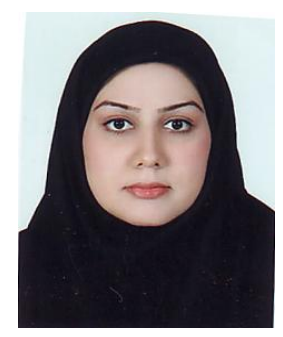

Farnaz Farrokh Alaee was born in Iran in 1978. She obtained her B.A and MA in TEFL (Teaching English as a Foreign Language) as a top student from Azad University of Mashhad and Ferdowsi University of Mashhad, Iran, respectively. She has taught English as a foreign language in different private institutes and schools in Mashhad to different levels. 